\title{
Application of Marketing Techniques in Library Services and Challenges Faced by University Librarians in Sri Lanka ${ }^{1}$
}

\author{
S. Shabnam Nishath ${ }^{2}$ and Sajeewanie D. Somaratna ${ }^{3}$
}

\begin{abstract}
Libraries should explore the marketing strategies to be used to promote their services among users, to entice new users and retain existing users. The objectives of this study were to find out the marketing techniques used in Sri Lankan university libraries and identify the challenges that university librarians face when marketing their services. The study involved 130 academic staff members of the libraries in 15 state universities established under the purview of the University Grants Commission in Sri Lanka. The total population was considered as the sample and the data were collected through self-administered questionnaire. The data were analyzed using the SPSS software package considering the mean and standard deviation. There were 105 valid questionnaires among returns, and the response rate was $80.8 \%$. As per the results, library websites, user orientation seminars, notice boards, and e-mail notifications were most frequently used to promote library
\end{abstract}

\footnotetext{
${ }^{1}$ This is the full paper of the abstract presented at the NILIS Research Symposium 2020 held on $23^{\text {rd }}$ January 2021 as a Webinar. Only one objective of this paper was presented at the conference.

${ }^{2}$ Assistant Librarian, University of Colombo, Sri Lanka.

Email: shabnam@lib.cmb.ac.lk iD https://orcid.org/0000-0003-2634-1682

${ }^{3}$ Senior Assistant Librarian, Faculty of Science, University of Colombo, Sri Lanka.

Email: sajees@lib.cmb.ac.lk iD https://orcid.org/0000-0003-1128-1330
} 
services. Mobile applications, blogs and podcasts were rarely used to promote library services in Sri Lankan universities. The mean ratings of perceived challenges in the marketing of library services by university librarians in Sri Lanka were considered. Lack of networking among librarians (3.54) was identified as a significant challenge faced by Sri Lankan university librarians when marketing their services. Other significant challenges were unawareness of library user requirements, insufficient funds for marketing, increased cost of marketing and lack of skills in marketing library services. This concludes that Sri Lankan university librarians market their library services using an array of techniques and come across various challenges while adopting marketing techniques to their services. To overcome these challenges libraries should consider appointing a marketing librarian for each university library and establish a collaboration between them, develop a unique marketing strategy for each library, and allocation of funds for marketing library services.

Keywords: Library Marketing Techniques, Library Services, University Librarians, University Libraries, Challenges in Marketing 


\section{Introduction}

University Librarians contribute significantly to the advancement of knowledge, research, and education in their respective universities. Academic/University Librarians strive to cater to the needs of their university community by implementing effective and efficient operations at their libraries. It is vital to keep the university community informed about the services provided by their respective university libraries. Awareness of library services among the university community will help demonstrate the existence of the university library within its community. To explain what libraries, do with their user groups, one possible strategy is to adopt marketing concepts.

As per the definition given by American Marketing Association (2017) marketing is "the activity, set of institutions, and processes for creating, communicating, delivering, and exchanging offerings that have value to customers, clients, partners, and society at large" (para. 2). Velasquez \& Campbell-Meier (2018) stated "marketing in a library context refers to the ability of a library to promote its collections, programs, and services to its community members" (p. 117).

The core objective of a library is to furnish its users with accurate information at the right time and place in the right manner. A university library needs to adopt marketing concepts, to survive and exceed other opponent organizations, to retain existing library users and to attract new users to the library. (Johoran, 2019, pp. 102-103)

The role of a library is steadily evolving in the twenty first century. Libraries must provide adequate services to the information seekers in the "Google Generation". Due to changes in the information 
needs of digital natives, the role of the traditional library also has shifted. Libraries may need to employ innovative marketing methods to suit the needs of digital natives. The problem is to depart from the traditional library's status quo.

Traditional libraries have long been concerned about the underutilization of their resources. The usual ways that librarians have been using to provide information to their users for the past few years should be reconsidered. Providing information for the "Google Generation" is a challenge for them. Therefore, there is a need to identify attractive ways of informing library users of the products and services offered by university libraries and to retain them in this competitive environment. There is a contextual gap, and this gap has been addressed in this research. The researchers have attempted to address this issue in the Sri Lankan context.

The purpose of this study was to identify the marketing techniques applied to promote the products and services of university libraries and the challenges that are being faced by university librarians in marketing their products and services. The objectives of this study were to find out the marketing techniques used in Sri Lankan university libraries and find out the challenges university librarians face when marketing their services. Following research questions were set to achieve these objectives.

1. What is the frequency of using marketing techniques to promote the library product and services?

2. What are the challenges university librarians face when marketing their services? 


\section{Literature Review}

Jose and Bhat (2007) reported "marketing according to Kotler (1982) is the analysis, planning, implementation, and control of carefully formulated programs designed to bring about voluntary exchanges of values with target markets to achieve organizational objectives" (p. 23).

The marketing mix is, using the combination of four "Ps", namely, Product, Price, Place, and Promotion, to achieve a target market. In 1960, Jerome E. McCarthy introduced the "Four Ps of marketing", and it was further developed by Kotler.

Librarians can apply marketing approaches such as the marketing mix in libraries and information centres as indicated at the identified five stages: determination of purpose and resources or product of the library; identification of competitors; identification of users; establishment of a marketing strategy for the library and use of the marketing mix method. (Ojiambo, 1994 as cited in Yi et al., 2013, p. 586)

According to Johoran (2019), a university library can adapt the marketing mix elements, namely product, price, place, and promotion to increase consumer satisfaction. In the context of a university library, consumers are the library users, and the marketing mix elements can be utilized/applied to increase customer satisfaction.

As explained by Onwubiko and Onu (2002), the use of marketing practices in academic libraries will help reach out to users who need the services but are not willing to seek the help of librarians (Onwubiko \& Onu, 2002, as cited in Chegwe \& Anaehobi, 2015).

Jayatissa \& Edzan (2002) in their study, had focused on information marketing in academic libraries in Sri Lanka. They stated 
that "academic libraries in Sri Lanka should aggressively market their services/products and must move from the provision of traditional library services (book loans) to a more IT based information service (Internet)" (p. 87).

According to Yi et al. (2013) "today, there is an increasing need for libraries to implement effective marketing techniques in response to external and internal pressures" (Enache, 2008, p. 478 as cited by Yi et al., 2013, p. 587). They further reported:

Because marketing has been an integral component of every library's day to day operation and librarians play a key role in marketing services and resources, there is a need for further research on the most effective techniques used and the impact that the related factors have on choosing these effective techniques. (p. 587)

"Surveys, pencils, screen savers, signage, college newspaper columns, and e-mail were described as effective marketing approaches" (Verostek, 2005, p. 119 as cited by Yi et al., 2013, p. 586).

In total, 30 approaches were used to market electronic resources in university libraries. "However, there was no information on which one was most effective and the factors influencing the techniques used" (Kennedy, 2010, p. 152 as cited by Yi et al., 2013, p. 586).

To keep pace with the evolving information technologies, librarians use a group of software applications including blogs, wikis, and podcasting, the media-sharing tools such as YouTube and Flickr, and the social networking services such as Twitter and Facebook to market their services and resources with mixed 
success. (Hinchliffe \& Leon, 2011; Moulaison \& Corrado, 2011 as cited by Yi et al., 2013, p. 587)

\section{Methodology}

The research population was academic staff members in the libraries of the 15 state universities established under the supervision of the University Grants Commission of Sri Lanka. These libraries have a total population of 130 academic staff members. In this study, total population sampling was used as the sampling method. Etikan (2016) stated that:

Leaving out some instances from the sample would have an incomplete puzzle with prominent pieces missing. In this instance, the best sampling method to use would be, the total population sampling. Total Population Sampling is commonly used when the number of cases being investigated is relatively small. (p. 3)

Therefore, the sample size of this study was the same as the population. Self-administered questionnaires were used to obtain primary data. Secondary data were collected through analyzing research articles of previous studies. The frequency of using marketing techniques to promote the library services was measured using a five point Likert scale. The Likert scale used was; always, often, sometimes, rarely, never. The marketing techniques were derived from literature. A five point Likert scale was used to find out the challenges that university librarians face when marketing their services. The Likert scale was: strongly agreed, agree, neither agree nor disagree, disagree and strongly disagree. The researcher has considered basic statistical parameters such as mean and 
frequencies to analyse the primary data using SPSS and Microsoft Excel. The mean value range for the $1^{\text {st }}$ research question was derived as; 1 to 1.80 denotes "Never", 1.81 to 2.60 denotes "Rarely", 2.61 to 3.40 denotes "Sometimes", 3.41 to 4.20 denotes "Often", 4.21 to 5.00 denotes "Always".

\section{Results and Discussion}

Out of 130 participants, 105 had responded to the questionnaire. The response rate of the study was $80.8 \%$. The first objective was to find out the marketing techniques used in Sri Lankan university libraries. This was achieved by considering how frequently different marketing techniques were used to promote library products and services.

Table 1 depicts mean ratings of the frequency of marketing techniques used in university libraries in Sri Lanka. Library Website (4.79), user orientation seminars (4.53), notice boards (4.29), and e-mail notifications (4.28) were the marketing techniques that Sri Lankan university librarians use most frequently to promote their library services.

As per the results, university librarians have stated that they often use marketing techniques such as library tours (4.20), formal lectures on library resources (4.07), Facebook (3.63), leaflets/brochures/pamphlets (3.53), poster (3.47), and corporate identity \& corporate image (3.47) to promote their services.

Marketing techniques such as signage (3.35), personal selling (3.24), library newsletter (3.14), publicity and public relations (3.12), bulk SMS service (3.09), exhibition (2.95), YouTube (2.84), and Twitter (2.69) were used only sometimes by university librarians to promote their service. 
Marketing techniques such as mobile applications (2.55), blogs (2.41), and podcasts (2.30) were rarely used by university librarians to promote their services.

\section{Table 1}

Mean Ratings of the Frequency of Marketing Techniques Used in University Libraries in Sri Lanka

\begin{tabular}{|c|c|c|c|}
\hline $\mathrm{S} / \mathrm{N}$ & Marketing Techniques & Mean & $\begin{array}{c}\text { Std. } \\
\text { Deviation }\end{array}$ \\
\hline 1 & Library Website & 4.79 & 0.494 \\
\hline 2 & User orientation seminars & 4.53 & 0.589 \\
\hline 3 & Notice board & 4.29 & 0.863 \\
\hline 4 & E-mail notifications & 4.28 & 0.803 \\
\hline 5 & Library tours & 4.20 & 1.051 \\
\hline 6 & Formal lectures on library resources & 4.07 & 1.04 \\
\hline 7 & Facebook & 3.63 & 1.613 \\
\hline 8 & Leaflets/Brochures/Pamphlets & 3.53 & 1.209 \\
\hline 9 & Poster & 3.47 & 1.01 \\
\hline 10 & $\begin{array}{l}\text { Corporate identity \& corporate image (i.e., } \\
\text { maintain the library image) }\end{array}$ & 3.47 & 1.066 \\
\hline 11 & Signage & 3.35 & 1.344 \\
\hline 12 & Personal selling & 3.24 & 1.275 \\
\hline 13 & Library Newsletter & 3.14 & 1.457 \\
\hline 14 & $\begin{array}{l}\text { Publicity and public relations (e.g.: writing } \\
\text { newspaper articles about their libraries) }\end{array}$ & 3.12 & 1.174 \\
\hline 15 & Bulk SMS service & 3.09 & 1.367 \\
\hline 16 & Exhibition & 2.95 & 1.032 \\
\hline 17 & YouTube & 2.84 & 1.618 \\
\hline 18 & Twitter & 2.69 & 1.613 \\
\hline 19 & Mobile applications & 2.55 & 1.366 \\
\hline 20 & $\mathrm{~B} \log \mathrm{s}$ & 2.41 & 1.511 \\
\hline 21 & Podcast & 2.30 & 1.531 \\
\hline
\end{tabular}


Table 2 further depicts the distribution of responses received on the frequency of using different marketing techniques in Sri Lankan university libraries. As per the results, 86 out of 105 respondents have mentioned that library websites are most frequently used in their libraries as a marketing technique. It indicates that, Library Website is the most used marketing technique of Sri Lankan university libraries to promote their products and services.

\section{Table 2}

The Distribution of Responses on the Frequency of Marketing Techniques used in University Libraries in Sri Lanka.

\begin{tabular}{|c|c|c|c|c|c|c|}
\hline $\mathrm{S} / \mathrm{N}$ & $\begin{array}{c}\text { Marketing } \\
\text { Techniques }\end{array}$ & Always & Often & Sometimes & Rarely & Never \\
\hline 1 & Library Website & 86 & 17 & 1 & 1 & 0 \\
\hline 2 & $\begin{array}{l}\text { User orientation } \\
\text { seminars }\end{array}$ & 61 & 39 & 5 & 0 & 0 \\
\hline 3 & Notice board & 53 & 34 & 13 & 5 & 0 \\
\hline 4 & $\begin{array}{l}\text { E-mail } \\
\text { notifications }\end{array}$ & 48 & 42 & 11 & 4 & 0 \\
\hline 5 & Library tours & 55 & 27 & 16 & 3 & 4 \\
\hline 6 & $\begin{array}{l}\text { Formal lectures on } \\
\text { library resources }\end{array}$ & 43 & 38 & 17 & 2 & 5 \\
\hline 7 & Facebook & 49 & 19 & 9 & 5 & 23 \\
\hline 8 & $\begin{array}{l}\text { Leaflets/ } \\
\text { brochures/ } \\
\text { pamphlets }\end{array}$ & 27 & 32 & 22 & 18 & 6 \\
\hline 9 & Poster & 15 & 39 & 36 & 10 & 5 \\
\hline 10 & $\begin{array}{l}\text { Corporate identity } \\
\& \text { corporate image } \\
\text { (i.e., maintain the } \\
\text { library image) }\end{array}$ & 18 & 36 & 33 & 13 & 5 \\
\hline
\end{tabular}




\begin{tabular}{llccccc}
\hline S/N & \multicolumn{1}{c}{$\begin{array}{c}\text { Marketing } \\
\text { Techniques }\end{array}$} & Always & Often & Sometimes & Rarely & Never \\
& & & & & \\
\hline 11 & Signage & 24 & 32 & 21 & 13 & 15 \\
12 & Personal selling & 20 & 26 & 32 & 13 & 14 \\
13 & Library Newsletter & 23 & 27 & 20 & 12 & 23 \\
14 & Publicity and & 11 & 33 & 32 & 16 & 13 \\
& public relations & & & & & \\
& (e.g.: Writing & & & & & \\
& newspaper articles & & & & & \\
& about their & & & & & \\
& libraries) & & & & & \\
15 & Bulk SMS service & 20 & 24 & 24 & 19 & 18 \\
16 & Exhibition & 4 & 30 & 39 & 21 & 11 \\
17 & YouTube & 22 & 23 & 16 & 4 & 40 \\
18 & Twitter & 23 & 18 & 4 & 23 & 37 \\
19 & Mobile & 10 & 19 & 25 & 16 & 35 \\
& applications & & & & & \\
20 & Blogs & 16 & 13 & 14 & 17 & 45 \\
21 & Podcast & 18 & 7 & 13 & 17 & 50 \\
\hline
\end{tabular}

These findings reflect the arguments given by Yi (2016) and Garoufallou et al., (2013). The study conducted by Yi (2016), revealed that Australian academic librarians perceived, social media and library websites as the most effective promotional techniques. As per the results indicated in the study of Garoufallou et al., (2013), Brochures/leaflets/pamphlets and websites were more frequently used as marketing techniques in Greek academic libraries. Further Yi, et al. (2013), Verostek (2005), Hinchliffe and Leon (2011), Benson et al. (2016) and Kaur and Rani (2008) had come across similar findings, in the studies they have carried out in Academic Libraries in United States, Australia, Nigeria, India, and Malaysia. 
To achieve the second objective of the study, librarians were asked to indicate their level of agreement with the statements on perceived challenges in marketing library services. Table 3 indicates the mean values of perceived challenges in marketing library services by university librarians in Sri Lanka.

\section{Table 3}

The Mean Values of Perceived Challenges in Marketing Library Services by University Librarians in Sri Lanka

\begin{tabular}{|c|c|c|c|}
\hline $\mathrm{S} / \mathrm{N}$ & Statements & Mean & $\begin{array}{c}\text { Std. } \\
\text { Deviation }\end{array}$ \\
\hline 01 & Marketing is costly for university libraries & 3.05 & 1.050 \\
\hline 02 & $\begin{array}{l}\text { Marketing subject is not taught at higher } \\
\text { Degrees (e.g.: Master's Degree in LIS) }\end{array}$ & 2.79 & 1.115 \\
\hline 03 & Lack of skills in marketing library services & 3.17 & 1.078 \\
\hline 04 & $\begin{array}{l}\text { Librarians do not know how to inform about } \\
\text { their services }\end{array}$ & 2.96 & 1.037 \\
\hline 05 & Afraid of commercial publicity & 2.79 & 1.016 \\
\hline 06 & Librarians unaware of the term marketing & 2.60 & 1.043 \\
\hline 07 & Inadequate funding for marketing & 3.35 & 1.101 \\
\hline 08 & Lack of networking among librarians & 3.54 & 1.233 \\
\hline 09 & $\begin{array}{l}\text { High level of information illiteracy among } \\
\text { library users }\end{array}$ & 2.87 & 1.020 \\
\hline 10 & Unaware of library user needs & 3.20 & 1.013 \\
\hline 11 & $\begin{array}{l}\text { Unawareness of using ICT to market } \\
\text { information products }\end{array}$ & 2.95 & 1.032 \\
\hline
\end{tabular}


As per the results depicted in Table 3, the statement "Lack of networking among librarians" had the highest mean score (mean 3.54). Networking among professional colleagues is a form of marketing strategy used to promote information products and services. Lacking such a strategy has been identified as a significant challenge by university librarians in Sri Lanka. The second highest challenge perceived by librarians was "inadequate funding for marketing" (mean 3.35). Lack of skills in marketing library services, unawareness of library user needs, and increased cost of marketing techniques were found as other challenges faced by university librarians in Sri Lanka.

It was found that librarians were aware of the term marketing (mean 2.60). Respondents showed disagreements on the statements such as librarians do not know how to market their services (mean 2.96), unawareness of using ICT to market information products (mean 2.95), high level of information illiteracy among library users (mean 2.87), marketing subject is not taught at higher degrees (mean 2.79), and afraid of commercial publicity (mean 2.79).

Further, an open ended question was included in the questionnaire. 14 out of 105 respondents had answered this question. The responses were summarized into 10 phases as follows.

1) Lack of time to do marketing

2) Insufficient staff members

3) Lack of skilled staff members

4) Lack of frequent updates on new trends in library marketing

5) Insufficient support from higher authorities/stakeholders

6) Negligence of library programs by higher authorities

7) Unawareness of the importance of marketing library services 
8) Attitudinal issues/Changes in attitude

9) Mainly librarians think that marketing is not needed for library services

10) Language barriers

These findings are compatible with the theoretical arguments presented by Chegwe and Anaehobi (2015) in their study carried out in Delta State, Nigeria. They reported that academic librarians in Delta State, Nigeria:

Faced with some challenges in marketing library services such as the library's casual approach to supplying information to potential users, cost of marketing, non-inclusion of marketing as a course in the curriculum of library schools, ignorance on the concept of marketing and lack of support from library management. (p. 21)

\section{Conclusion and Recommendations}

When considered the overall findings, marketing techniques such as library websites, user orientation seminars, notice boards, and e-mail notifications were most frequently used by Sri Lankan university libraries to promote their library products and services. Techniques like blogs, podcasts and mobile applications have rarely been used to promote library services at Sri Lankan universities.

Librarians perceived the lack of professional networking between university librarians and libraries as the greatest challenge in marketing their products and services. Networking among professional colleagues is a form of marketing strategy used to promote information products and services. The establishment of a fruitful network among librarians has 
been identified as a significant challenge by university librarians in Sri Lanka.

Librarians also perceived several other challenges such as inadequate funding for marketing, unawareness of library user needs, increased cost of marketing and lack of skills in marketing library services. According to the study, librarians at Sri Lankan universities are very familiar with marketing techniques.

Based on the findings of the research study following recommendations are made to overcome the issues in the marketing of library services in Sri Lankan universities.

- Establish a collaborative network among university libraries and librarians in Sri Lanka.

A marketing librarian for each library should be appointed and form a collaborative network among them. Sri Lankan university libraries could form a consortium that includes all the marketing librarians from each university. Through this consortium, they will be able to share their unique marketing strategy with the sister libraries. In return, it will create a pool of ideas and resources that can be used to serve a larger community in Sri Lankan universities. It is also important to educate the university community about the importance and value of the library in this new Google era. By adopting such a marketing strategy, university libraries could promote their services among their user communities.

- Allocate adequate funding for marketing.

A separate allocation should be made annually for the promotional activities of library services. For example, the preparation of brochures, banners, posters, and newsletters involve production cost, therefore needs an allocation of funds. 
- Train library staff to improve their marketing skills.

Marketing can be done based on the way the staff interacts with the library users. The staff can be trained to provide a friendly service to the users, which will attract more users to the library. Workshops, seminars, etc., can be organized to improve the marketing skills of the library staff. This training will make them capable of delivering an effective service to the users.

- Develop a marketing plan for each university library.

In addition to appointing a "Marketing Librarian", it is recommended that a marketing plan be developed for each library. The marketing librarian may prepare this plan for a given period, based on four important stages such as investigation, segmentation, promotion, and evaluation. At the "investigation" phase, the marketing librarian should identify their users' information needs. This may be accomplished through user surveys, observations, interviews, etc. with library users. Under "segmentation", identify the domains, categories of users where marketing techniques will be used. The "promotion" stage includes all the techniques, activities that can be used to promote library services. Finally, an "evaluation" would be necessary to ensure the success of the marketing plan.

In this study, the researchers had focused on university libraries in Sri Lanka as the target group. Future research may be conducted by considering the marketing techniques used at different categories of libraries in Sri Lanka, such as public libraries, school libraries, special libraries, etc., and the challenges faced by those librarians while practicing these marketing techniques. 


\section{References}

American Marketing Association. (2017). Definitions of marketing. https://www.ama.org/the-definition-of-marketing-what-ismarketing/

Benson, O. V., Udo-anyanwu, A. J., \& Onuoha, C. O. (2016). Strategies used in marketing library and information services in tertiary institutions in Imo State. Journal of Applied Information Science and Technology, 9(1), 144-152.

Chegwe, A. O., \& Anaehobi, S. E. (2015). Academic librarians perception and attitude towards marketing of library services in Delta State, Nigeria. Library Philosophy and Practice, 1, 1-24.

Etikan, I. (2016). Comparison of convenience sampling and purposive sampling. American Journal of Theoretical and Applied Statistics, 5(1), 1-4. https://doi.org/10.11648/j.ajtas.20160501.11

Garoufallou, E., Zafeiriou, G., Siatri, R., \& Balapanidou, E. (2013). Marketing applications in Greek academic library services. Library Management, 34(8/9), 632-649. https://doi.org/10.1108/LM-032012-0012

Hinchliffe, L. J., \& Leon, R. (2011). Innovation as a framework for adopting web 2.0 approaches. Marketing libraries in a web 2.0 world. In D. Gupta, \& R. Savard (Eds.), Proceedings of the 2010 Satellite Preconference of the Mangement and Marketing Section of the International Federation of Library Associations and Organizations (pp. 57-65). De Gruyter.

Jayatissa, B., \& Edzan, N. N. (2002). Information marketing in Sri Lankan academic libraries. Malaysian Journal of Library \& Information Science, 07(02), 87-100. 
Johoran, S. S. (2019). Application of marketing mix elements to improve customer satisfaction of main library, University of Colombo. Journal of the University Librarians Association of Sri Lanka, 22(2), 102-118. https://doi.org/10.4038/jula.v22i2.7940

Jose, A., \& Bhat, I. (2007). Marketing of library and information services:

A strategic perspective. Vision: The Journal of Business Perspective, $\quad 11(2), \quad 23-28 . \quad$ https://doi.org/10.1177/ 097226290701100204

Kaur, A., \& Rani, S. (2008). Marketing of information services and products in university libraries of Punjab and Chandigarh (India): An attitudinal assessment of library professionals. Library Management, 29(6/7), 515-537. https://doi.org/10.1108/ 01435120810894536

Velasquez, D. L., \& Campbell-Meier, J. (2018). Marketing practices in Australian libraries: Is promotion enough? Journal of the Australian Library and Information Association, 67(2), 116-130. https://doi.org/10.1080/24750158.2018.1466429

Verostek, J. M. (2005). Affordable, effective, and realistic marketing. College \& Undergraduate Libraries, 12(1-2), 119-138.

Yi, Z. (2016). Effective techniques for the promotion of library services and resources. Information Research, 21(1). https://files.eric.ed.gov/ fulltext/EJ1094561.pdf

Yi, Z., Lodge, D., \& McCausland, S. (2013). Australian academic librarians' perceptions of marketing services and resources. Library Management, 34(8), 585-602. https://doi.org/10.1108/LM-01-20130002 